\title{
Auxospore fine structure and variation in modes of cell size changes in Grammatophora marina (Bacillariophyta)
}

\author{
Shinya Sato ${ }^{1 *}$, David G. Mann ${ }^{2}$, Tamotsu Nagumo ${ }^{3}$, Jiro Tanaka ${ }^{4}$, Tomoya Tadano ${ }^{5}$ and Linda K. Medin ${ }^{1}$ \\ ${ }^{1}$ Alfred Wegener Institute for Polar and Marine Research, Am Handelshafen 12, D-27570 Bremerhaven, Germany \\ ${ }^{2}$ Royal Botanic Garden, Edinburgh EH3 5LR, Scotland, UK \\ ${ }^{3}$ Department of Biology, The Nippon Dental University, 1-9-20 Fujimi, Chiyoda-ku, 102-8159 Tokyo, Japan \\ ${ }^{4}$ Department of Ocean Sciences, Tokyo University of Marine Science and Technology, 4-5-7 Konan, Minato-ku, \\ 108-8477 Tokyo, Japan \\ ${ }^{5}$ Doris Japan co. ltd., 2-34-24 Izumihoncho, Komae-City, Tokyo, Japan
}

\begin{abstract}
S. Sato, D.G. Mann, T. Nagumo, J. Tanaka, T. Tadano and L.K. Medlin. 2008. Auxospore fine structure and variation in modes of cell size changes in Grammatophora marina (Bacillariophyta). Phycologia 47: 12-27. DOI: 10.2216/ 07-34.1

Examination of Grammatophora marina from rough and clonal cultures showed that cell size changes were more flexible than is generally reported for diatoms. Allogamous sexual auxosporulation took place through copulation between small male cells and larger female cells, but only in mixed rough culture and never in clonal cultures. Auxospores were also formed without copulation in clonal cultures ('uniparental auxosporulation') and these, like sexual auxospores, developed through formation of a perizonium, which consisted of a series of transverse bands. All of these bands, including the primary band, were open. Circular scales were present in the auxospore wall before initiation of perizonium formation and irregular, elongate structures lined the suture of the transverse perizonium. Perizonium and scales resembled those of another araphid pennate diatom, Gephyria media. Initial cells were formed within the perizonium and consisted of an initial epivalve with a simplified structure, an initial hypovalve (formed beneath the perizonium suture) and a third, normally structured valve formed beneath the epivalve; the epivalve was then sloughed off. Initial cells of similar configuration but often aberrant morphology could also be formed through expansion from vegetative cells, without involvement of a perizonium. Vegetative cells were also capable of limited enlargement through simple expansion without formation of an initial cell, and abrupt size reduction. Cell size ranges in populations from different regions suggest that $G$. marina may contain pseudocryptic species.
\end{abstract}

Key Words: Abrupt cell size reduction, Auxospore, Diatoms, Fine structure, Grammatophora marina, Life cycle, Perizonium, Scales, Vegetative cell enlargement

\section{INTRODUCTION}

In most diatoms, a progressive diminution of cells in size occurs with vegetative divisions. When a certain size is reached and if environmental conditions are suitable, gametogenesis is triggered; the successful fusion of gametes results in a zygote, termed the auxospore, which then expands in volume. In turn, the expanded auxospore gives rise to an initial cell, which is the largest cell of the life cycle, thus restoring cell size to a maximum characteristic of the species or population (Round et al. 1990; Edlund \& Stoermer 1997). This diatom-specific mode of life cycle is well known (e.g. Bold \& Wynne 1985; South \& Whittick 1987), but there are exceptions: (1) several diatoms are known to be able to increase cell size without auxosporulation and (2) abrupt cell size reduction can occur (Chepurnov et al. 2004). Geitler (1932) proposed that there are cardinal points in the life history of a diatom, characterized by particular cell sizes and marked by physiological and/or cytological changes in the cells (see also Chepurnov et al. 2004). In this study, an araphid diatom, Grammatophora

* Corresponding author (shinya.sato@awi.de). marina (Lyngbye) Kützing, was examined in culture to investigate its life cycle.

Grammatophora Ehrenberg is a genus of marine araphid diatoms, whose cells attach to each other by mucilage pads to form zig-zag colonies (Round et al. 1990; Sato et al. 2004a). Grammatophora marina is a cosmopolitan species in coastal areas, and is often abundant (Witkowski et al. 2000). Along the coasts of Japan, for instance, this species is sometimes dominant on the thalli of Porphyra spp. that are cultivated e.g. for nori production. Such attached diatoms consume nutrients around the Porphyra and also change the colour and taste of nori so that its value is reduced (Ohgai et al. 1988); they are therefore regarded as nuisance algae. An understanding of the life cycle of G. marina may therefore be valuable for industry, as well as having biological interest.

According to von Stosch \& Drebes (1964, p. 211) sexual reproduction of $G$. marina occurs dioeciously and some features of auxosporulation have been described from natural populations by Karsten (1926), Lebour (1930) and Magne-Simon (1960, 1962). These authors showed that (1) sexualized small cells become attached to a chain of large cells; (2) the small cells and the larger cells to which they are attached differentiate into gametangia; (3) each gametangium produces one gamete; (4) the smaller gametangia 
Table 1. Strains of Grammatophora marina examined in this study.

\begin{tabular}{|c|c|c|c|c|c|}
\hline $\begin{array}{c}\text { Strain no. } \\
\text { (voucher no.) }\end{array}$ & Observed phenomena & $\begin{array}{l}\text { Collecting } \\
\text { date }\end{array}$ & $\begin{array}{l}\text { Observation } \\
\text { date }\end{array}$ & Locality & Collector \\
\hline$\overline{\mathrm{AA}} 1^{1}$ & $\begin{array}{l}\text { allogamous sexual } \\
\text { auxosporulation }\end{array}$ & Apr. 2004 & 14 May 2004 & Galveston Bay, Texas, USA & W. Wardle \\
\hline SKR $5-1^{1}$ & $\begin{array}{l}\text { vegetative initial cell } \\
\text { formation }\end{array}$ & 03 Apr. 2003 & 14 Apr. 2003 & $\begin{array}{l}\text { Rinnkou Park, Kanagawa } \\
\text { Pref., Japan }\end{array}$ & S. Sato \\
\hline s0050 (Zu6/22) & $\begin{array}{l}\text { uniparental } \\
\text { auxosporulation }\end{array}$ & 05 Apr. 2004 & 08 Nov. 2004 & $\begin{array}{l}\text { English Channel, Roscoff, } \\
\text { France }\end{array}$ & K. Valentin \\
\hline $\mathrm{s} 0050 / 01^{2}(\mathrm{Zu} 6 / 23)$ & abrupt cell size reduction & 24 Jul. $2005^{3}$ & 16 Oct. 2005 & & \\
\hline s0074(Zu6/24) & vegetative cell enlargement & Apr. 2004 & 06 Oct. 2005 & Galveston Bay, Texas, USA & W. Wardle \\
\hline s0130(Zu6/25) & abrupt cell size reduction & 24 Feb. 2004 & 21 Feb. 2005 & Port Park, Chiba Pref., Japan & T. Tadano \\
\hline s0136(Zu6/26) & vegetative cell enlargement & 24 Feb. 2004 & 21 Feb. 2005 & Port Park, Chiba Pref., Japan & T. Tadano \\
\hline
\end{tabular}

\footnotetext{
${ }^{1}$ Sample no., because observation was done using a rough culture. Voucher slide was not deposited.

${ }^{2} \mathrm{~F} 1$ generation of s0050.

${ }^{3}$ Re-isolation date from s0050 strain.
}

produce active 'male' cells, whereas the gametes produced by the large cells are passive ('female'); (5) fertilization occurs inside the female theca; (6) the auxospore expands by adding many transverse perizonial bands; and (7) the initial cells are formed inside the auxospores. These observations were made by light microscopy (LM). Magne-Simon (1962) studied Feulgen-stained material of natural populations and was able to demonstrate stages in meiosis, the expulsion of one nucleus into a small residual cell at meiosis I, and the degeneration of one daughter nucleus at meiosis II to leave a single functional nucleus in each mature gametangium. Fusion of the male and female nuclei took place soon after plasmogamy, before the auxospore expanded.

In the past $40 \mathrm{yr}$, information about auxospore structure has greatly increased (e.g. Crawford 1974; Mann 1982a, 1989; von Stosch 1982; Cohn et al. 1989; Kaczmarska et al. 2000, 2001; Schmid \& Crawford 2001; Nagumo 2003; Sato et al. 2004b; Amato et al. 2005; Tiffany 2005; Toyoda et al. 2005, 2006; Pouličková \& Mann 2006). However, although it has become clear that some aspects of the fine structure of auxospores have phylogenetic significance at higher taxonomic levels (e.g. Medlin \& Kazcmarska 2004), there is still insufficient information to reveal how the structure and development of auxospores have evolved in the major diatom groups, especially among the lineages of araphid pennate diatoms. Indeed, the only detailed information available concerning araphid pennates is the account of Rhabdonema arcuatum Kützing by von Stosch $(1962,1982)$ and the scanning electron microscopy (SEM) study of Gephyria media Arnott by Sato et al. (2004b). In the present study, we report details of auxospore formation in $G$. marina, using LM and SEM.

\section{MATERIAL AND METHODS}

Vegetative cells of G. marina were collected in Japan, North America and Europe (Table 1). Initially, periphytic diatoms were removed from their seaweed hosts or substrata and inoculated into Petri dishes to establish rough cultures. Within a week, single cells or short cell chains were isolated into clonal culture. Each sample was maintained in IMR medium (Eppley et al. 1967) at $15^{\circ} \mathrm{C}$ under cool-white fluorescent light on a 14:10 light: dark photoperiod, at a photon flux density of $30-40 \mu \mathrm{mol}$ photons $\mathrm{m}^{-2} \mathrm{~s}^{-1}$. Two other media were used to induce vegetative initial cell formation and vegetative cell enlargement, respectively: silica-enriched (45 mg ${ }^{-1} \mathrm{Na}_{2} \mathrm{SiO}_{3} .9 \mathrm{H}_{2} \mathrm{O}$ ) KW21 medium (Daiichi Seimo, Kumamoto, Japan, available at http:// www.seimo.co.jp/KW21-English.htm), and double-strength IMR with soil extract. Strains were reinoculated approximately once per month, except strain s0050/01, which was kept c. 3 mo without transfer.

LM observations were made using Zeiss Axioplan (Zeiss, Oberkochen, Germany) or Olympus BH-2 (Tokyo, Japan) microscopes with bright field or differential interference contrast optics; preparations were made as described in Nagumo (2003) unless stated otherwise. To photograph live specimens (Figs 5-8), we used an inverted microscope (ID02, Zeiss) equipped with a Panasonic DMC-FX5 digital camera (Matsushita Electric Industrial, Osaka, Japan). For the observation of vegetative initial cell formation (Figs 30, 31 ), we used an Olympus CK2 inverted microscope with integral digital camera (Camedia C-3020, Olympus). For SEM, specimens were treated by three different methods. After rinsing with distilled water, intact cells were either (1) air-dried onto the cover glass or (2) cleaned by the bleaching method introduced by Nagumo \& Kobayasi (1990); alternatively, (3) cells were freeze-dried to keep auxospore structure intact. For this, cells were fixed with $10 \%$ glutaraldehyde for $2 \mathrm{~h}$ at $4^{\circ} \mathrm{C}$, rinsed with distilled water several times to remove glutaraldehyde, and dehydrated using increasing amounts of t-butyl alcohol; then they were freeze-dried using an ID-2 instrument (Eiko Engineering, Ibaraki, Japan). After mounting specimens onto glass cover-slips, extra cells and dust particles were removed with a glass needle under LM. Cover-slips were fixed onto SEM stubs with carbon tape and specimens were coated with $\mathrm{Pt}-\mathrm{Pd}$ using an E-1030 ion sputter coater (Hitachi, Tokyo, Japan), or with gold using SC 500 (Emscope, Ashford, UK). S-4000 (Hitachi) and QUANTA 200F (FEI Company, Eindhoven, The Netherlands) SEMs were used at accelerating voltages of 3,5 or $10 \mathrm{kV}$, and c. $10 \mathrm{~mm}$ working distance. All captured images were 

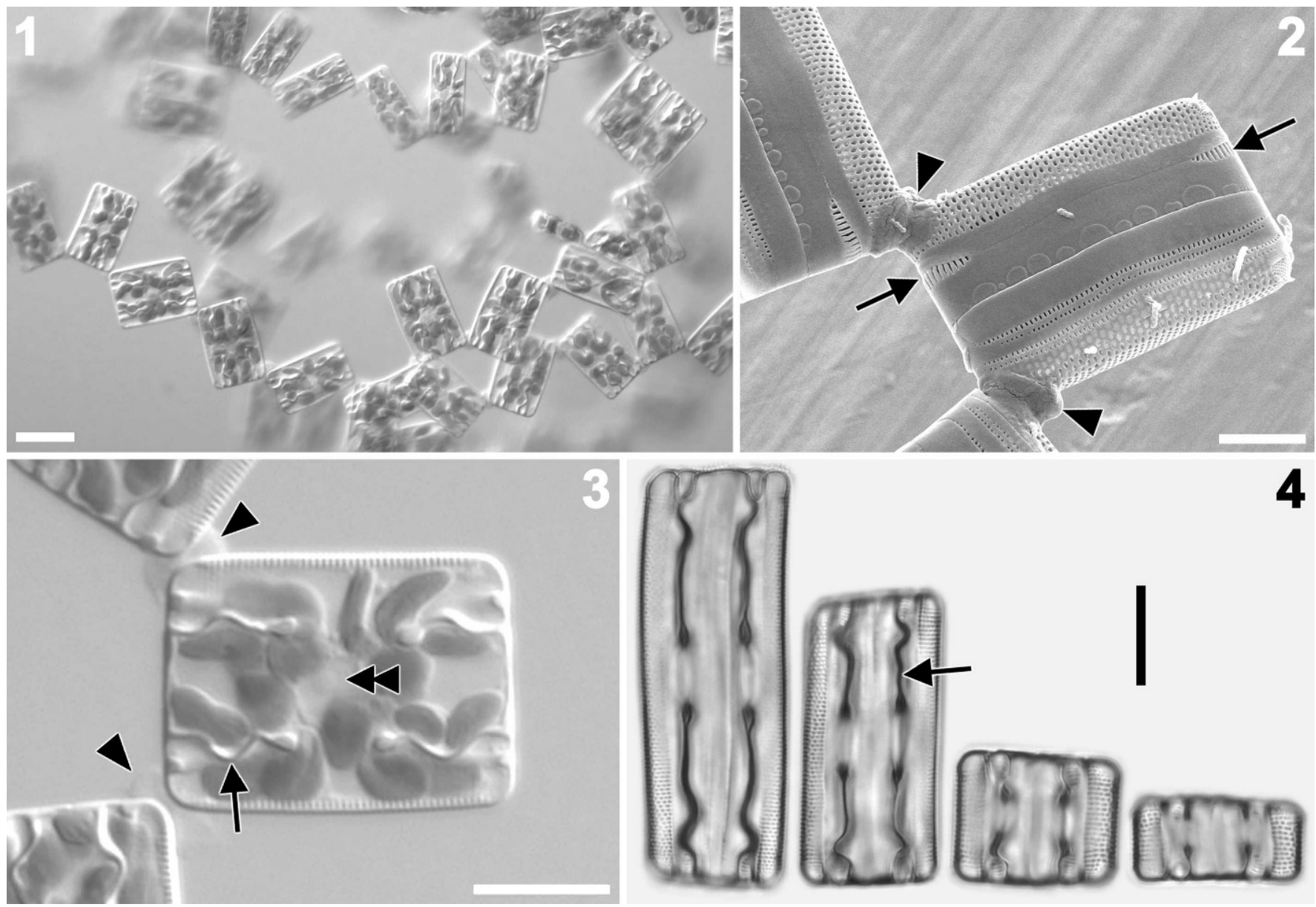

Figs 1-4. Vegetative phase of Grammatophora marina (natural material). Light microscopy (Figs 1,3 , 4) and SEM (Fig. 2). Scale bars $=$ $20 \mu \mathrm{m}$ (Fig. 1), $5 \mu \mathrm{m}$ (Fig. 2) and $10 \mu \mathrm{m}$ (Figs 3, 4).

Fig. 1. Zig-zag chains of living cells.

Fig. 2. Attachment of a cell to its neighbour via mucilage (arrowheads) secreted from apical pore fields (cf. Fig. 27). Areas of slits on both ends of the valvocopula secrete no mucilage (arrows).

Fig. 3. Living colony in girdle view, showing mucilage pads linking the cells (arrowheads). The central nucleus (double arrowhead) is surrounded by elongate chloroplasts, which extend around the septa (arrow)

Fig. 4. Cleaned and mounted cells in girdle view. Gradual cell size reduction is accompanied by changes in pervalvar depth and in the shape of the septa (e.g. arrow).

adjusted with Adobe Photoshop. Digitally saved LM and SEM images were used for measurements of valve length using Scion Image (http://www.scioncorp.com). Voucher specimens of cleaned material of the clonal cultures were mounted as permanent slides and have been deposited in the Hustedt Collection, Alfred Wegener Institute, Bremerhaven, Germany (Voucher no. Zu6/22-26, Table 1).

Terminology follows Anonymous (1975) and (particularly for auxospore structures) Round et al. (1990). Molecular phylogenetic studies of diatoms have revealed that historical diatom classifications do not reflect a natural system and araphid pennate diatoms are paraphyletic in most gene phylogenies, e.g. using nuclear $18 \mathrm{~S}$ ribosomal DNA (rDNA) and plastid 16S rDNA (Medlin \& Kaczmarska 2004). Nevertheless, we use the terms araphid and centric here, because they refer to key morphological features or their absence. In this paper, the term araphid pennate diatom follows the traditional definition, i.e. a diatom that has an elongate valve with a central or slightly lateral sternum, apical pore fields and often also apical rimoportulae, but that lacks a raphe slit. We do not imply that this corresponds to a mono- (holo-) phyletic group, or that it should be accorded any taxonomic status.

\section{RESULTS}

\section{Vegetative cells}

In culture, cells formed zig-zag colonies (Figs 1-3), as in nature. Both valves secreted mucilage from apical pore fields, either from the same end of the cell or from opposite ends (Figs 2, 3). Rimoportulae were located at the both ends of the valve (data not shown; see Sato et al. 2004a). The most advalvar girdle band (valvocopula) was a complete hoop, from which septa extended inward from both poles (Figs 3, 4). In larger cells, the septa formed undulating siliceous plates, each pierced by a hole at the centre, opposite the nucleus (Figs 3, 4). The septa became less strongly undulate with cell size reduction and finally 

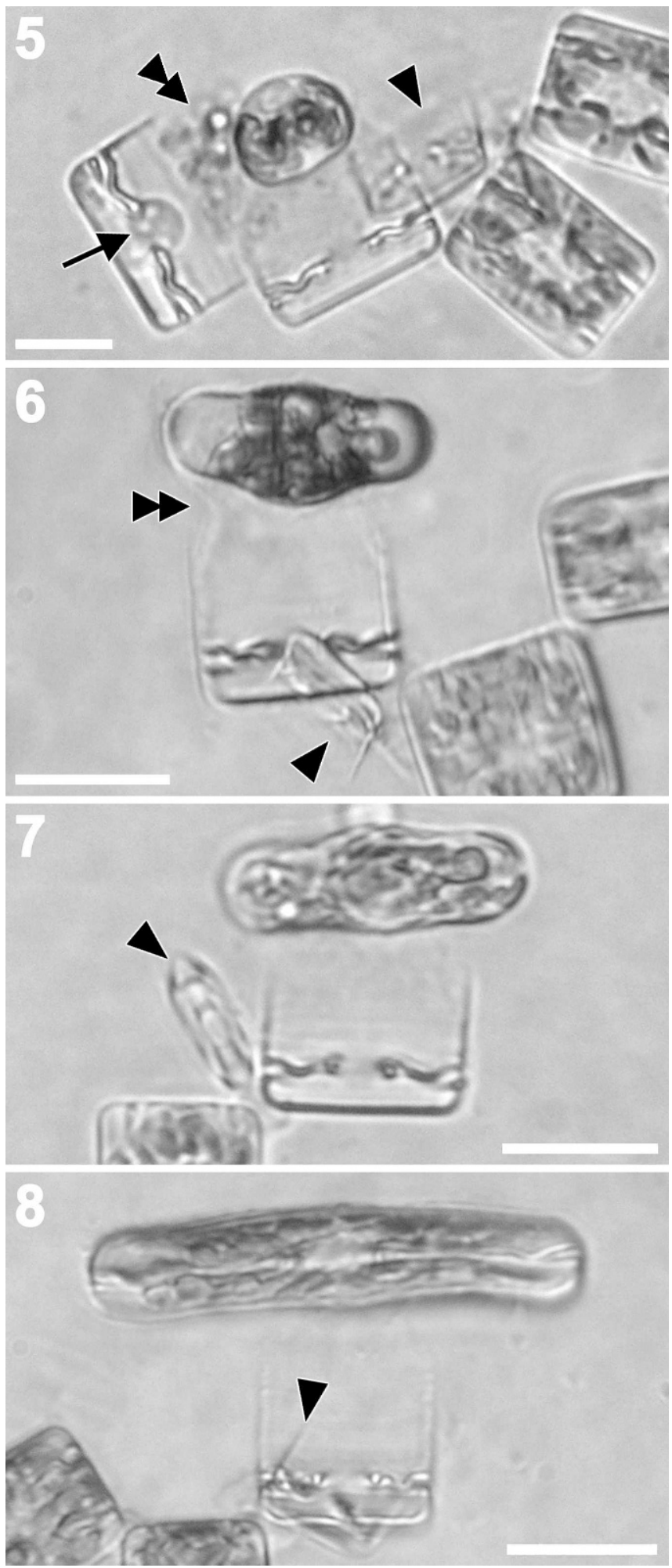

Figs 5-8. Allogamous sexual auxosporulation of Grammatophora marina. Rough culture of sample AA1, light microscopy. Empty male gametangia are indicated by arrowheads. Scale bars $=20 \mu \mathrm{m}$.

Fig. 5. Early stage of auxospore development. The fertilized zygote has just vacated the female gametangium, leaving a small residual body (arrow). A degenerate chloroplast is also present (double arrowhead).

Figs 6, 7. Expanding auxospores. Mucilage (double arrowhead) connects the auxospore to the female gametangium.
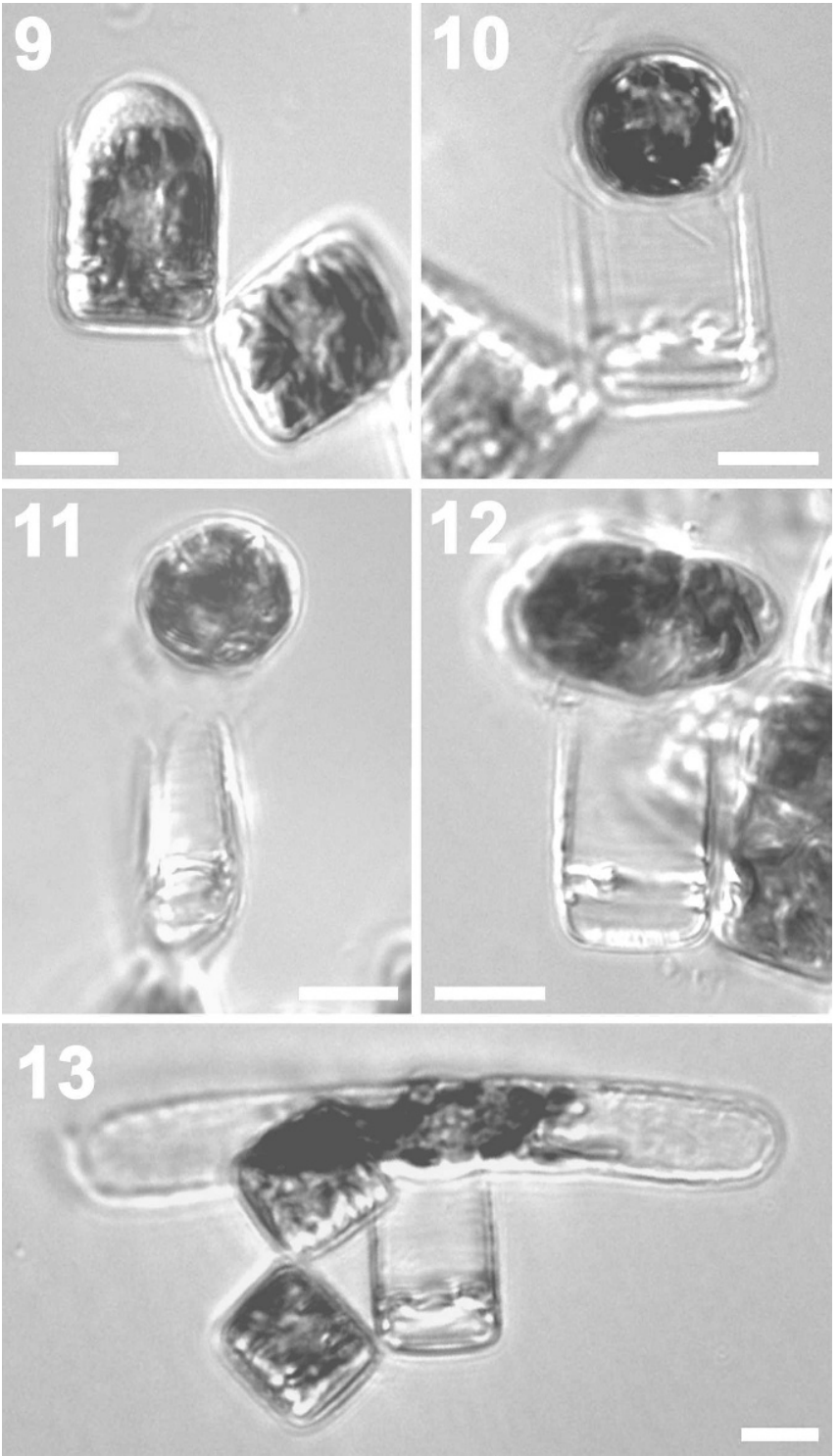

Figs 9-13. Uniparental auxosporulation of Grammatophora marina. Clone s0050, light microscopy. Scale bars $=10 \mu \mathrm{m}$.

Fig. 9. Preauxospore stage: the free surface of the protoplast has rounded off following loss of the upper theca.

Figs 10, 11. Young spherical auxospore near the mother-cell theca.

Fig. 12. Expanding auxospore.

Fig. 13. Mature auxospore (as yet without initial valves).

became planar (Fig. 4). The valvocopula bore several slits at each pole (Fig. 2) but the function of the slits was unclear, because no mucilage was secreted from them (Fig. 2, see also Figs 26, 42, 50). No other perforations were present in the valvocopula. As many as five additional bands (copulae) were present in the epicingulum and each had one or two rows of round areolae (Fig. 2). The nucleus was located in the centre of the cell (Fig. 3). Elongate or

$\leftarrow$

Fig. 8. Mature auxospore containing initial cell. In this example, the male cell is almost completely out of focus (line at arrowhead). 
Table 2. Parental and initial cell lengths ${ }^{1}$ of this study and from literature.

\begin{tabular}{|c|c|c|c|}
\hline Mode of reproduction & Mother cell ${ }^{2}(\mu \mathrm{m})$ & Male cell $(\mu \mathrm{m})$ & Initial cell $(\mu \mathrm{m})$ \\
\hline $\begin{array}{l}\text { Allogamous sexual } \\
\text { auxosporulation }\end{array}$ & $19.4-24.7(21.8 \pm 1.4): 17$ & $13.6-15.9(14.8 \pm 1.2): 3$ & $52.3-70.4(63 \pm 5.8): 9$ \\
\hline $\begin{array}{l}\text { Allogamous sexual } \\
\text { auxosporulation }\end{array}$ & $30-70$ & $20-50$ & $122.9-158.3(137.2 \pm 11.53): 8^{4}$ \\
\hline Uniparental auxosporulation & $14.7-20.3(16.8 \pm 1.7): 7$ & - & $68.8-96.3(84.3 \pm 8.5): 9$ \\
\hline Vegetative initial cell formation & $16-20(17.9 \pm 1.9): 5$ & - & $66-73.5(69.3 \pm 2.7): 6$ \\
\hline
\end{tabular}

lobed chloroplasts were present throughout the cell, although their distribution was constrained by the presence of the septa.

\section{Auxosporulation}

Auxospores were formed in both rough cultures and clonal cultures. Auxosporulation as a result of gametic fusion was observed in a rough culture during a few weeks after inoculation into the medium. As described by previous authors, copulation took place between small male cells and larger female cells. Each male cell was solitary and became attached to the mucilage pad connecting the female cell to an adjacent large cell (Figs 6, 7), or apparently to the adjacent cell itself (Fig. 5). The mechanism by which sexualized male and female cells became juxtaposed was unclear. Only a single auxospore was produced by each pair of copulating cells and it was always formed above the larger gametangium (Figs 5-8), confirming that the single male gamete is active and the single female is essentially passive. Empty male thecae remained attached to the female chain after plasmogamy (Figs 5-8). Female gametangia became elongate in the pervalvar direction through the addition of extra girdle bands to the hypotheca (Fig. 6): c. 10 were present (Fig. 15), compared to $3-5$ in vegetative cells (Fig. 2). Addition of extra bands was not observed in male gametangia.

Nuclear behaviour was not observed in this study and the earliest stage directly observed was the freeing of the zygote from the female gametangium (Fig. 5). Extracellular material apparently containing degenerating chloroplasts was visible near the zygote (Fig. 5) and a residual body of cytoplasm was present within one of the thecae of the female gametangium, adhering to one of the septa (Fig. 5). The young auxospore was connected to the female gametangium by a mucilage envelope (Fig. 6). The auxospore expanded at right-angles to the pervalvar axis of the gametangium and parallel to its longitudinal axis (Figs 6-8). No caps were observed on the ends of the auxospores at any stage during expansion. Mature auxospores possessed a delicate perizonium (see below) and were cylindrical and often slightly arcuate, with a convex dorsal side (Fig. 8).

No sexual auxosporulation was observed in clonal cultures, but single auxospores were nevertheless produced (Figs 9-13). These auxospores were never accompanied by smaller cells, or by empty male thecae. We refer to this phenomenon as uniparental auxosporulation. We were unable to establish whether this represented autogamic reproduction (fusion of haploid nuclei within an undivided protoplast after meiosis) or apomixis (absence of meiosis and parthenogenetic development of an unfertilized egg cell). The subsequent expansion and development of the auxospores were identical to allogamous sexual auxosporulation. However, there was a significant difference in initial cell size between the two methods of auxosporulation, with those produced sexually being smaller (Table 2).

\section{Scales}

Scales of various sizes and shapes were observed on both sexually produced and uniparental auxospores. Auxospores that had emerged from their mother cells but had not yet begun to expand were covered with circular scales (Figs 14 16). Expanding auxospores possessed transverse perizonial bands, but these were overlain by scales (Fig. 17). Scales could still be found in the final stages of expansion and development, even after the initial epivalves had been formed, although there appeared to be fewer of them and they no longer formed a complete covering (Fig. 27). Each scale had an annulus, which bore irregularly branching fimbriae. Within the annulus, the scale was often weakly or only irregularly and partly silicified (Fig. 18).

\section{Fine structure of the perizonium}

The transverse perizonium developed as the auxospore expanded; young auxospores (Figs 17, 19) therefore had many fewer bands than mature ones (Fig. 26). The primary (central) band (Figs 19-21, 23, 25) was wider than the secondary bands that flanked it on either side and it was also symmetrical, having a central axis and equal fringes of fimbriae. All of the transverse perizonial bands (including the primary band) were open and aligned, forming a distinct, wide suture parallel to the long axis of the auxospore (Figs 19, 20, 22, 23). We will refer to the side occupied by the suture as 'ventral' and this side always lay closest to the female gametangial cell wall from which the auxospore emerged.

All of the transverse perizonial bands consisted of two parts: (1) a rib along the long axis of the band and (2) two rows of irregularly branching fimbriae (Figs 19-25). The bands were tightly associated and the distal fringe of fimbriae overlapped the proximal fringe of the next band 

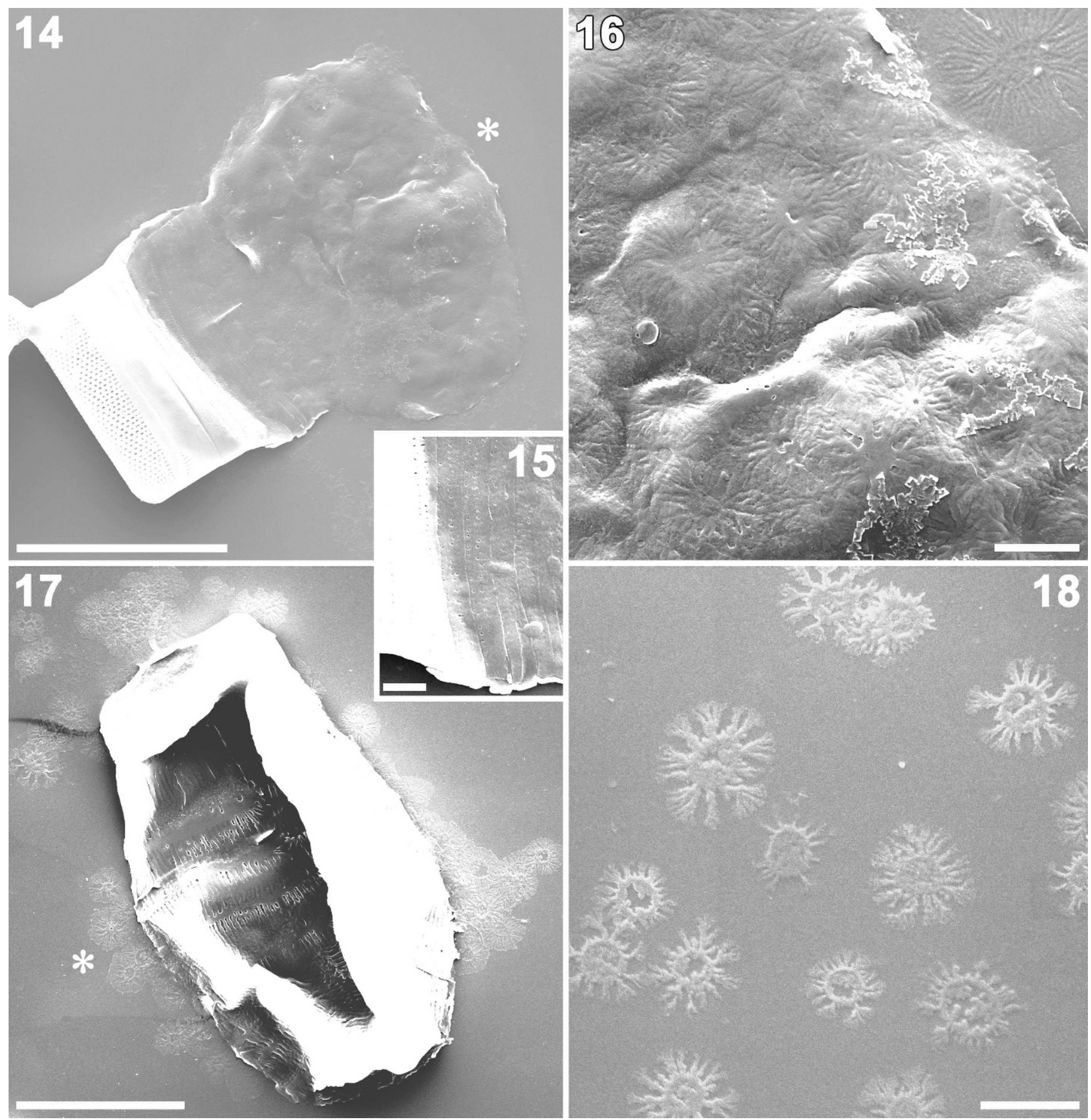

Figs 14-18. Auxospore scales of Grammatophora marina, SEM. Rough culture AA1 (Figs 14-16) and clone s0050 (Figs 17, 18). Scale bars $=10 \mu \mathrm{m}$ (Figs 14, 17) and $2 \mu \mathrm{m}$ (Figs 16, 18).

Fig. 14. Young auxospore recently emerged from the mother cell, before perizonium formation.

Fig. 15. Detail of mother-cell girdle, showing numerous copulae.

Fig. 16. Enlargement of Fig. 14 (at asterisk) showing circular scales on the surface of the auxospore.

Fig. 17. Partly expanded auxospore with transverse perizonial bands, in high contrast to show the scales that have dropped around the auxospore.

Fig. 18. Scales with annuli surrounded by fimbriae.

(Figs 19, 20, 22-24); the proximal and distal fringes are therefore analogous to the pars interior and pars exterior, respectively, of diatom girdle bands. The fimbriae of the pars interior were slightly shorter than those of the pars exterior (Fig. 24, pi and pe). On the ventral side, the open ends of the primary transverse perizonial bands were centripetally curved, whereas on the dorsal side the bands were strictly parallel (Fig. 29; see also Figs 19, 23). The primary transverse perizonial band had double-length fringes and a somewhat broader rib (Figs 19, 20, 23), 

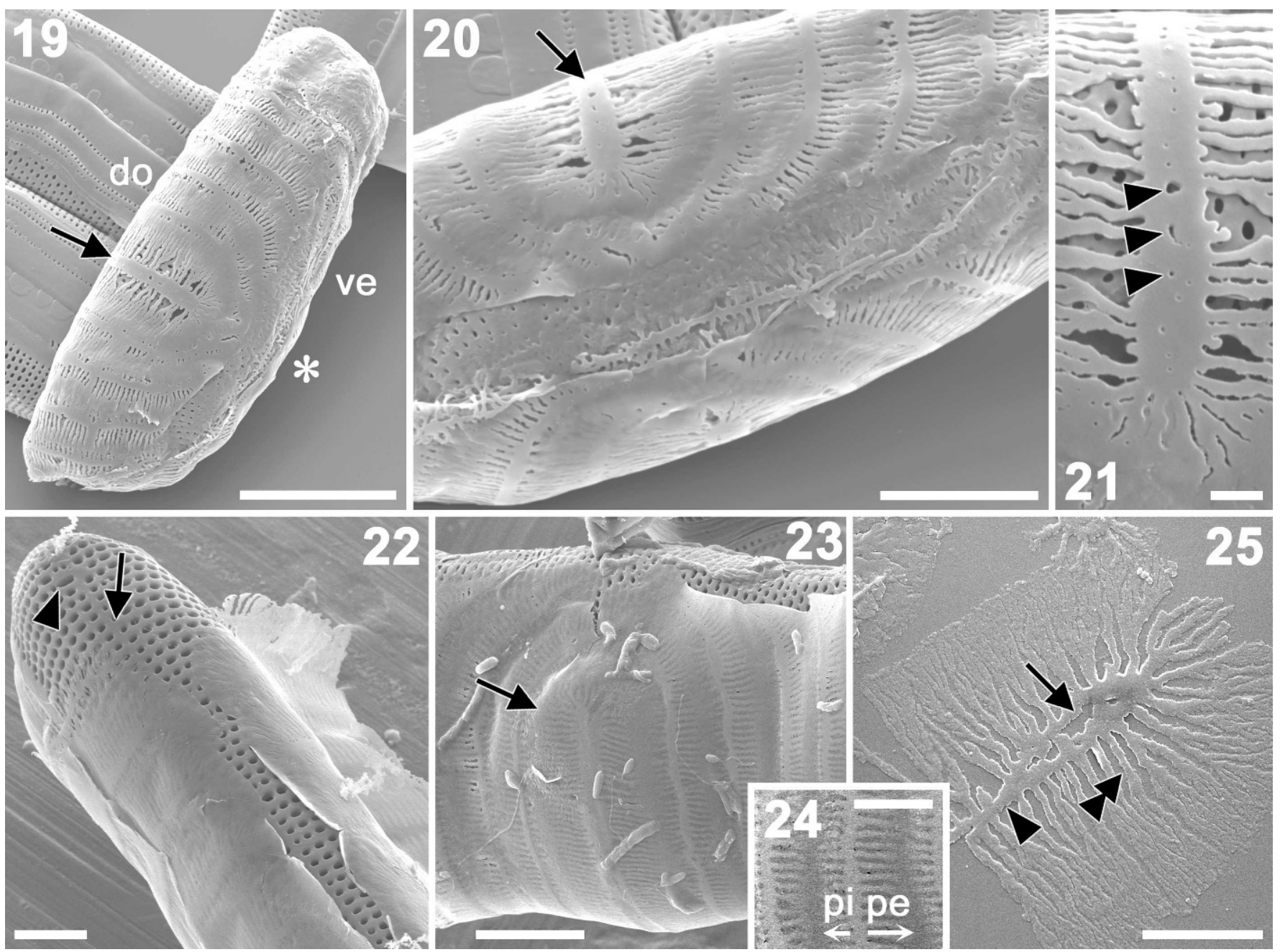

Figs 19-25. Perizonium of Grammatophora marina, SEM. Clone s0050. Scale bars $=10 \mu \mathrm{m}$ (Fig. 19), $5 \mu \mathrm{m}$ (Figs 20,23$), 1 \mu \mathrm{m}$ (Fig. 21$)$ and $2 \mu \mathrm{m}$ (Figs 22, 24 and 25).

Fig. 19. Small auxospore covered with transverse perizonial bands. Note the wider, symmetrical primary transverse band (arrow). The dorsal (do) and ventral (ve) sides are marked.

Fig. 20. Detail of the part marked with asterisk in Fig. 19, showing the suture, where irregular siliceous structures are located. The end of the primary transverse band (arrow) is visible.

Fig. 21. Primary transverse band, with pores along the central rib (arrows).

Fig. 22. Ventral side of a mature auxospore, showing the suture and underlying initial hypovalve. None of the irregular longitudinal structures remain. The exterior opening of a rimoportula is visible (arrowhead) in the hypovalve, which has a normal striation extending out from the sternum (arrow).

Fig. 23. Central part of mature auxospore showing the transverse perizonium bands, which are all asymmetrical apart from the primary band (arrow).

Fig. 24. Detail of the secondary transverse perizonial bands: in each, the distal fimbriae (the pars exterior: pe) are longer than the proximal fimbriae (forming the pars interior: pi).

Fig. 25. Tip of an isolated primary transverse band, showing an annulus-like development (arrow) of the primary rib (arrowhead). The primary rib bears secondary ribs (double arrowhead) on each side, which then split up into finer ribs, forming a fringe of fimbriae.

although the latter was also somewhat shorter because of the size of the fimbriae. The primary band rib often had pores along its centre (Fig. 21) and in a few specimens it had a hoop-like end resembling an annulus (Fig. 25).

During intermediate stages of auxospore development, irregular, elongate silicified structures were observed along the suture on the ventral side of the auxospore (Fig. 20). Although these structures were also found on mature auxospores encasing the initial cell, there were considerably fewer than during earlier stages of development. No longitudinal perizonial band as seen in $R$. arcuatum (von
Stosch 1982) was observed in any stage of auxospore development.

\section{Initial cells and 'cardinal points'}

The initial cells produced by sexual or uniparental auxosporulation were nearly identical in morphology; they were straight or slightly curved and usually \pm symmetrical about the apical and median transapical planes. However, we also observed some initial cells that appeared to have been formed without auxosporulation and were not 

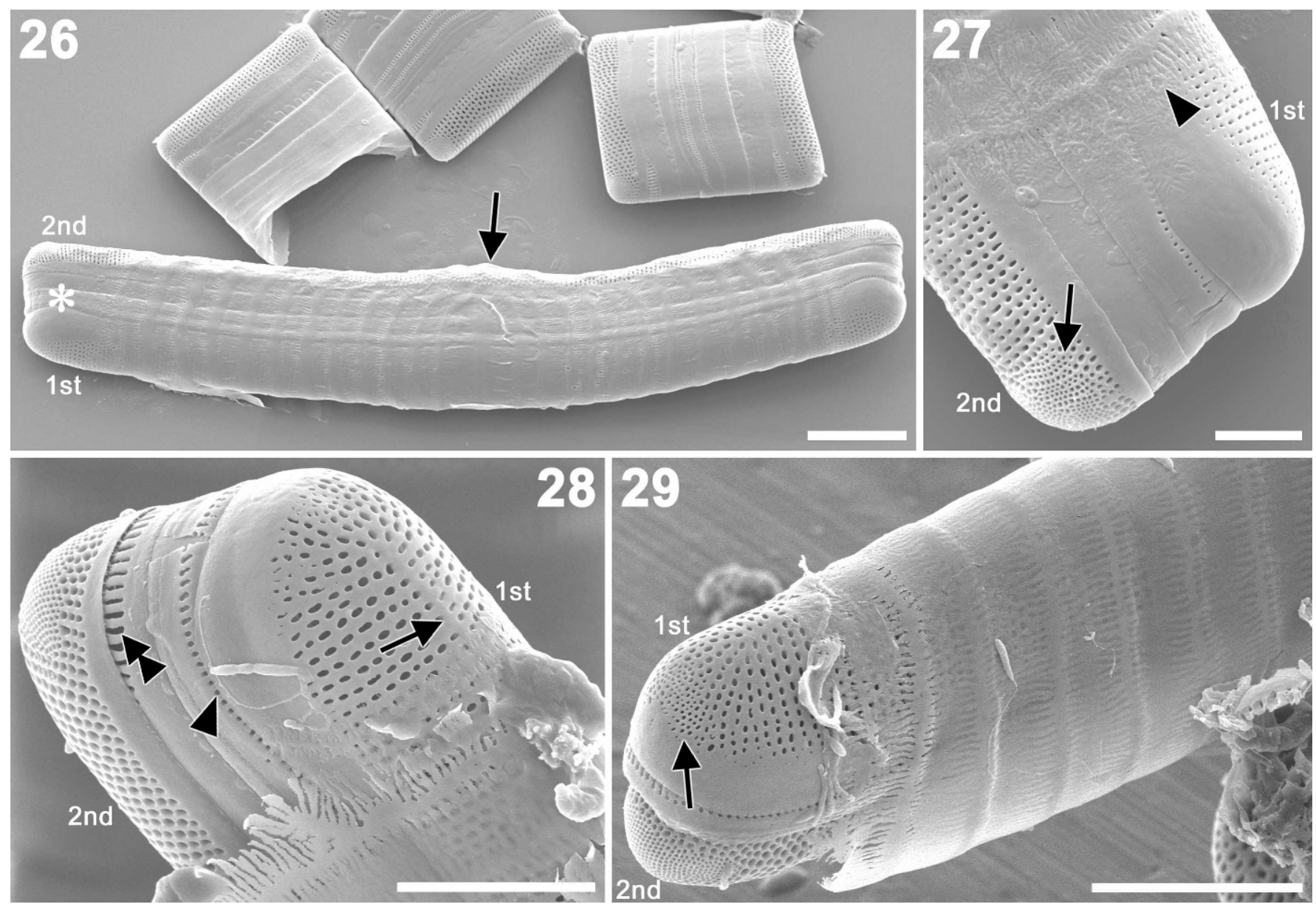

Figs 26-29. Initial cells of Grammatophora marina, SEM. Clone s0050. Valves are numbered in order of formation. Scale bars $=10 \mu \mathrm{m}($ Fig. 26), $3 \mu \mathrm{m}$ (Fig. 27) and $5 \mu \mathrm{m}$ (Figs 28, 29).

Fig. 26. Initial cell within the perizonium. The second (hypo-) valve has a slightly convex centre (arrow).

Fig. 27. Enlargement of the part marked with asterisk in Fig. 26. Note the difference in striation between the first and second valves. A few scales (arrowhead) are still present.

Fig. 28. End of initial cell. Note the prominent sternum (arrow) and the absence of an apical pore field in the first (epi-) valve, and the difference in striation between the valvocopulae of the initial epitheca (arrowhead) and the initial hypotheca (double arrowhead).

Fig. 29. Initial cell in which the initial epivalve has a much reduced apical pore field (arrow).

associated either with mating cells or with empty male thecae around the mother cell, indicating they had been formed without prior inter- or intraclonal mating. This phenomenon - which we will refer to as vegetative initial cell formation - was observed only in a rough culture. Whereas the initial cells formed through both sexual and uniparental auxosporulation were covered with scales and perizonium, the initial cell formed by vegetative initial cell formation had no trace of these coverings (Figs 30-38), despite use of preparation methods identical to those used for Figs 14-17. Abnormal cell outlines (e.g. Figs 37, 38) were much more frequent in these initial cells than in those formed through sexual or uniparental auxosporulation.

Vegetative initial cell formation differed from vegetative cell enlargement (below) in that initial epivalves were not produced after vegetative cell enlargement (Fig. 51). Initial epivalves differed from normal vegetative valves in having (1) no distinct valve mantle; (2) a wider valve margin (the plain strip of silica around the edge of the valve); and (3) small apical pore fields or none (Figs 27-29, 32-36). The valvocopulae associated with the initial epivalves also differed from those of vegetative cells, because they (1) lacked septa, (2) were narrower and more fragile, (3) lacked slits at the apices, and (4) possessed instead a single (or partly double) row of round or elliptical poroids (Figs 27-29).

The initial epitheca was produced on the dorsal side of the auxospore and the initial hypotheca was formed opposite, beneath the perizonial suture (Fig. 39). The initial hypovalve resembled a normal valve in shape and structure (Figs 27-29), except that its central portion was sometimes slightly swollen (Fig. 26), corresponding to a slight bulge in the auxospore where it abutted onto the gametangium (Figs 7, 13). The valvocopula of the initial hypotheca was also normal, possessing septa. The second valve had a valvocopula with septa (Figs 8, 39). Beneath the initial epivalve, a third valve with a septum-bearing valvocopula was formed to complete a frustule of \pm normal appearance (Figs 30, 39), whereupon the initial epivalve was sloughed off. Any abnormalities of shape in the initial cells were gradually lost during subsequent vegetative divisions (e.g. Fig. 30). Unlike vegetative cells and chains, the uniparentally produced initial cells often floated in the culture vessel. 


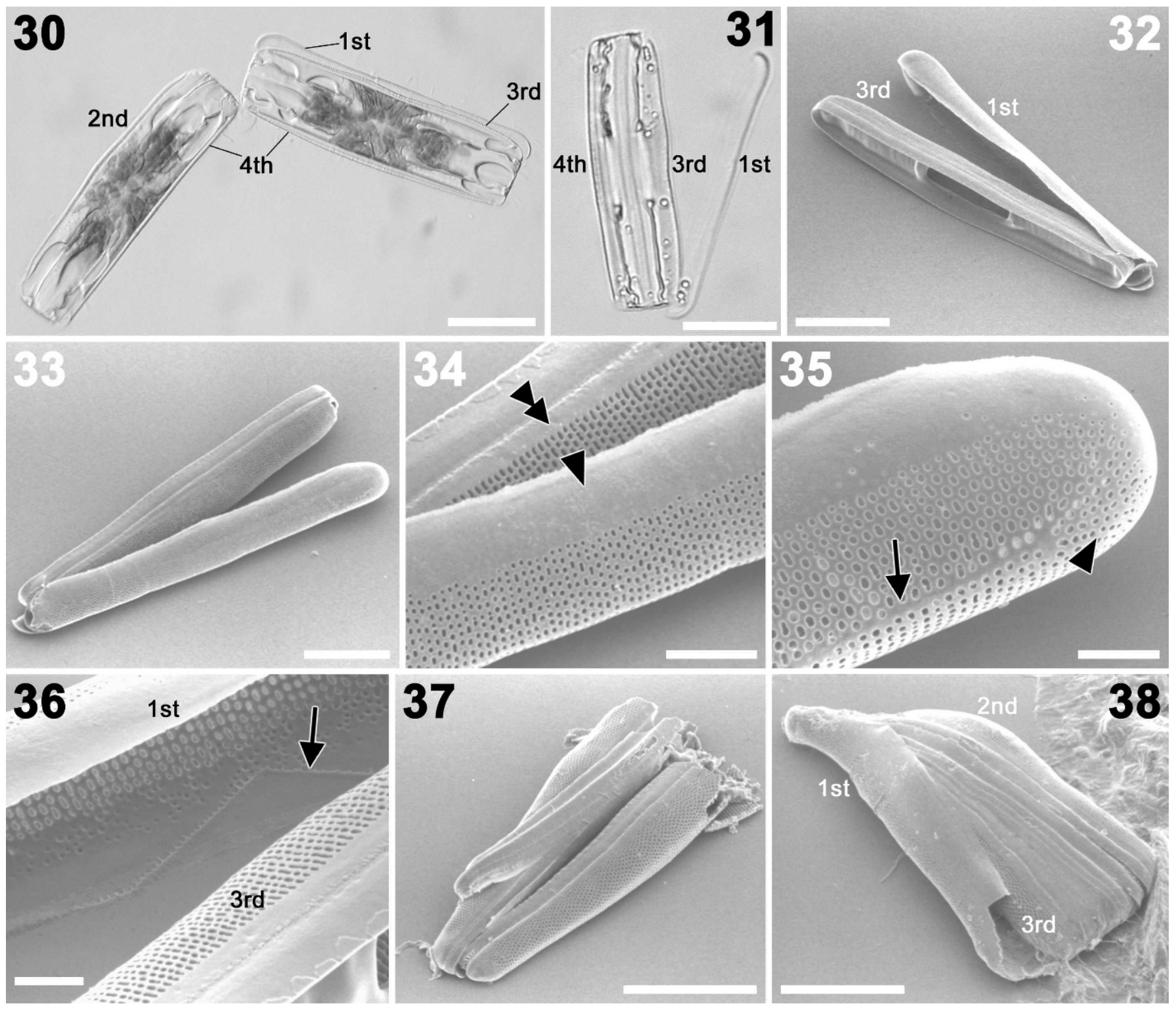

Figs 30-38. Initial cells of Grammatophora marina produced vegetatively. Light microscopy (Figs 30, 31) and SEM (Figs 32-38). Rough culture of SKR5-1 sample. Scale bars $=20 \mu \mathrm{m}$ (Figs 30-33), $5 \mu \mathrm{m}$ (Fig. 34), $3 \mu \mathrm{m}$ (Figs 35, 36) and $10 \mu \mathrm{m}$ (Figs 37, 38).

Figs 30-33. A recently divided initial cell, with valves numbered in order of formation. The daughter cells are shown (alive) in Fig. 30: the initial epivalve (first) is now superfluous, being replaced by a normally structured valve (third). Following treatment by the bleaching method, the daughter cell possessing the initial epivalve was studied in LM (Fig. 31) and SEM (Figs 32, 33).

Figs 34, 35. Enlargements of the centre (Fig. 34) and pole (Fig. 35) of the daughter cell of Figs 31-33. Note the broader valve margin of the initial epivalve (Fig. 34, arrowhead), relative to the vegetative valve beneath (double arrowhead). The initial epivalve has a prominent sternum (Fig. 35, arrow) and radially arranged pores at the apex (Fig. 35, arrowhead; contrast Figs 27-29).

Fig. 36. Interior of the initial epivalve of Figs 30-33. Note valvocopula of initial valve (arrow).

Figs 37, 38. Strongly deformed initial cell, in which one end has failed to develop properly.

The first cardinal point of diatom sexual reproduction concerns the size of the initial cells. The size range of initial cells produced by the three modes differed (Table 2). Initial cells produced by allogamous sexual auxosporulation were the smallest, being 52.3-70.4 $\mu \mathrm{m}$ (mean $=63 \mu \mathrm{m}$ ), as opposed to $68.8-96.3 \mu \mathrm{m}($ mean $=84.3 \mu \mathrm{m})$ with uniparental auxosporulation. This was surprising because (1) the sizes of the asexual mother cells (uniparental auxosporulation) and female gametangia (allogamous sexual auxosporulation) were comparable (indeed, the gametangia were larger on average) and (2) sexual auxospores also received a contribution of cytoplasm and organelles from the male gametangium. Vegetative initial cells were slightly larger than sexual initial cells (Table 2).

The second cardinal point is the upper size threshold for sexualisation and auxosporulation. The maximum size for a female cell in this study was $24.7 \mu \mathrm{m}$.

The third cardinal point is the critical minimal size for size restitution via auxospores, below which a clone will survive only through mitotic division and (in some cases) vegetative cell enlargement. The smallest cell observed to be capable of uniparental auxosporulation was $14.7 \mu \mathrm{m}$. The 


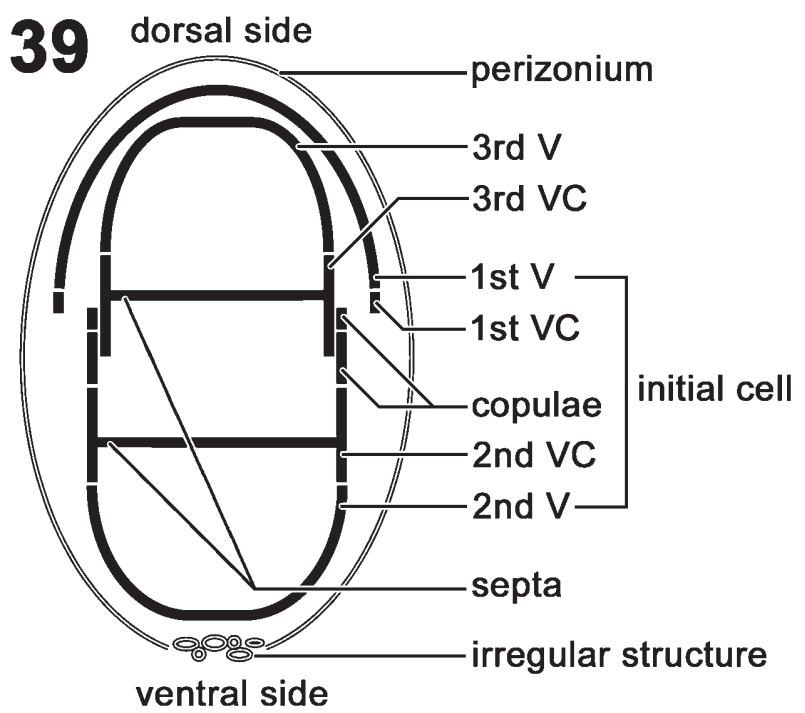

Fig. 39. Schematic section of the auxospore and initial cell. V, valve; VC, valvocopula.

smallest female sexual gametangium was $19.4 \mu \mathrm{m}$, and the smallest male was $13.6 \mu \mathrm{m}$. Because most of the male cells were attached to the females at an angle (e.g. Fig. 7), only three specimens were measurable, the largest $(15.9 \mu \mathrm{m})$ being smaller than any of the females measured.

\section{Abnormal cells}

Abnormal cells were detected in many of the culture strains of $G$. marina, with substantial differences in valve length between epi- and hypovalve (Figs 40-50). These appear to reflect not only abrupt reductions in size but also abrupt increases.

With abrupt cell size reduction, the apical dimension of the hypotheca was suddenly and drastically reduced (Figs 43-46, and presumably Fig. 40) by up to $50 \%$ relative to the epitheca. Reduction occurred spontaneously in old cultures (a few months after inoculation) and resulted from unequal division of parent cells; faulty division was presumably responsible too for producing cells with a constriction at one side of the frustule (Fig. 42), which were also frequent in old cultures.

In some cases, cells had larger hypothecae than epithecae (Figs 47-50), implying expansion before or during cell division. The alternative explanation - slippage and reconfiguration of the girdle bands during specimen preparation seems unlikely and so $G$. marina appears to be able to perform vegetative cell enlargement, which can produce a $25-100 \%$ increase, relative to the epitheca. This mode of enlargement could sometimes be induced by inoculation into double-strength IMR medium with soil extract.

\section{DISCUSSION}

\section{Auxospore coverings}

The first study of auxospore coverings using electron microscopy was a brief report of scales in the auxospore wall of Melosira varians Agardh with transmission electron microscopy (Reimann 1960). Since then, our knowledge of auxospore fine structure has gradually increased, revealing a diversity of structures, including scales of various shapes and sizes, and different kinds of properizonia (in bi- and multipolar centric diatoms) and perizonia (von Stosch 1982; Round et al. 1990). 'Perizonium' was apparently used by Reimann (1960) to refer to all kinds of auxospore wall, but the term is now restricted to the system of hoops and split bands (longitudinal and transverse) found in pennate diatoms (Round et al. 1990; Kaczmarska et al. 2001). The perizonium is accompanied by \pm circular scales in some but not all pennate diatoms. These include four araphid diatoms; $R$. arcuatum (von Stosch 1982), G. media (Sato et al. 2004b) and G. marina (this study), and also the raphid diatoms Pseudo-nitzschia multiseries (Hasle) Hasle (Kaczmarska et al. 2000, but not in Pseudo-nitzschia delicatissima (Cleve) Heiden: Amato et al. 2005) and Diploneis papula (Schmidt) Cleve (M. Idei in Kaczmarska et al. 2001). Recently, the auxospores of Nitzschia fonticola (Grunow) Grunow and Pinnularia cf. gibba have been shown to possess systems of fine transverse strips, lying outside the perizonium and formed before it (Trobajo et al. 2006; Poulíčková et al., in press). At least in Pinnularia cf. gibba, these strips are silicified and they may be homologous with the circular scales of the araphid pennates, Pseudo-nitzschia spp. and D. papula. Trobajo et al. (2006) have suggested that the parts of the auxospore wall that surround the perizonium and that are formed before it should be referred to as 'incunabula'. In $G$. marina and $G$. media, the incunabula would comprise the organic wall and circular scales of the auxospore, but not the elongate scales along the perizonial suture in G. marina (this study) or the 'elongate sprawling structure' in an equivalent position in G. media (Sato et al. 2004b).

The difference of the degree of silicification and the shape of the scales are different between those produced by sexual and uniparental auxosporulation (Figs 16 and 18, respectively). However, it is likely that these differences are not because of the mode of auxosporulation (i.e. sexual or uniparental), because a great diversity of the scale shape has also been reported on a single auxospore in centric diatoms, e.g. Arachnoidiscus ornatus Ehrenberg (Kobayashi et al. 2001) and Ellerbeckia arenaria (Moore) Crawford (Schmid \& Crawford 2001).

The primary (central) transverse perizonial band of $G$. marina is open on one side, as in R. arcuatum (von Stosch 1962) and G. media (Sato et al. 2004b). This is probably a primitive characteristic for pennate diatoms because the properizonium, which is presumably homologous to the perizonium but occurs in mediophycean centric diatoms (Medlin \& Kaczmarska 2004), also has an open central band (e.g. in Chaetoceros didymum Ehrenberg and Lithodesmium undulatum Ehrenberg: von Stosch 1982). On the other hand, in most raphid pennate diatoms, the primary transverse perizonial band is generally a complete hoop, e.g. in Amphora copulata (Kützing) Schoeman \& R.E.M. Archibald (Nagumo 2003), Caloneis cf. silicula (Mann 1989), Craticula cuspidata (Kützing) Mann (Cohn et al. 1989), Navicula cryptocephala Kützing (Poulíčková \& Mann 2006), Neidium affine (Ehrenberg) Pfitzer (Mann 

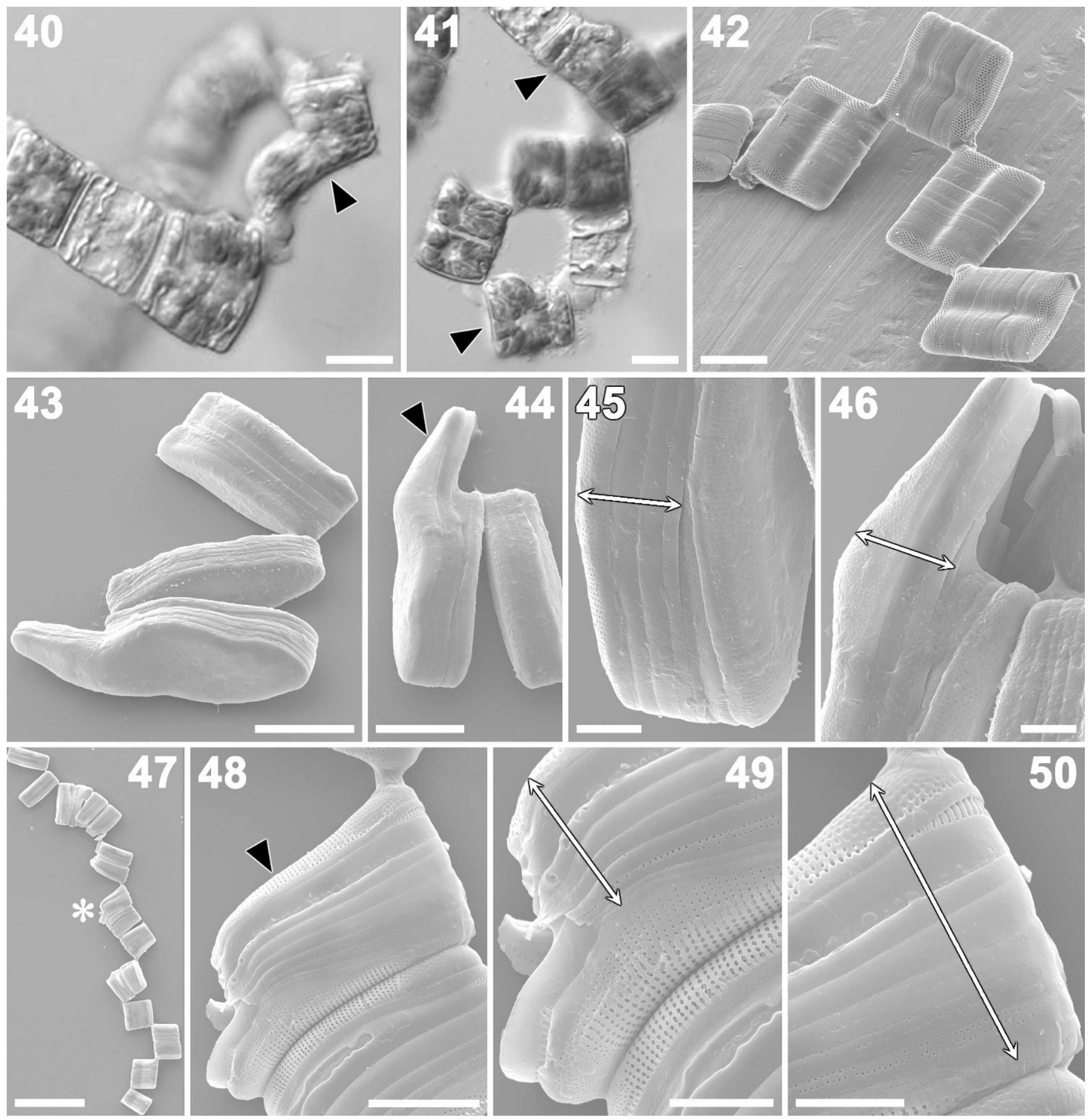

Figs 40-50. Abrupt cell size reduction and vegetative enlargement in Grammatophora marina. Light microscopy (Figs 40, 41) and SEM (Figs 42-50). Clone s0130 (Fig. 40), s0136 (Fig. 41), s0050/01 (Figs 42-46), s0074 (Figs 47-50). Scale bars = 10 $\mu \mathrm{m}$ (Figs 40, 41, 43 and 48 ), $20 \mu \mathrm{m}$ (Fig. 42), $5 \mu \mathrm{m}$ (Figs 45, 46, 49 and 50) and $50 \mu \mathrm{m}$ (Fig. 47).

Fig. 40. Abrupt cell size reduction. Arrowhead indicates cell with large epitheca and considerably smaller hypotheca.

Fig. 41. Vegetative cell enlargement. Arrowheads indicate the cell with small epitheca and larger hypotheca that gave rise to the chain of larger cells.

Fig. 42. Zig-zag colony in which abrupt cell size reduction has taken place. Note that one side of each cell has a constriction.

Figs 43-46. Abrupt cell size reduction. Arrowhead and arrows indicate the epitheca in the overall view (Fig. 44) and details (Figs 45, 46) of the cell in which size reduction occurred.

Figs 47-50. Vegetative cell enlargement in the cell indicated by an asterisk in Fig. 47. The arrowhead and arrows indicate the position and extent of the epitheca. 


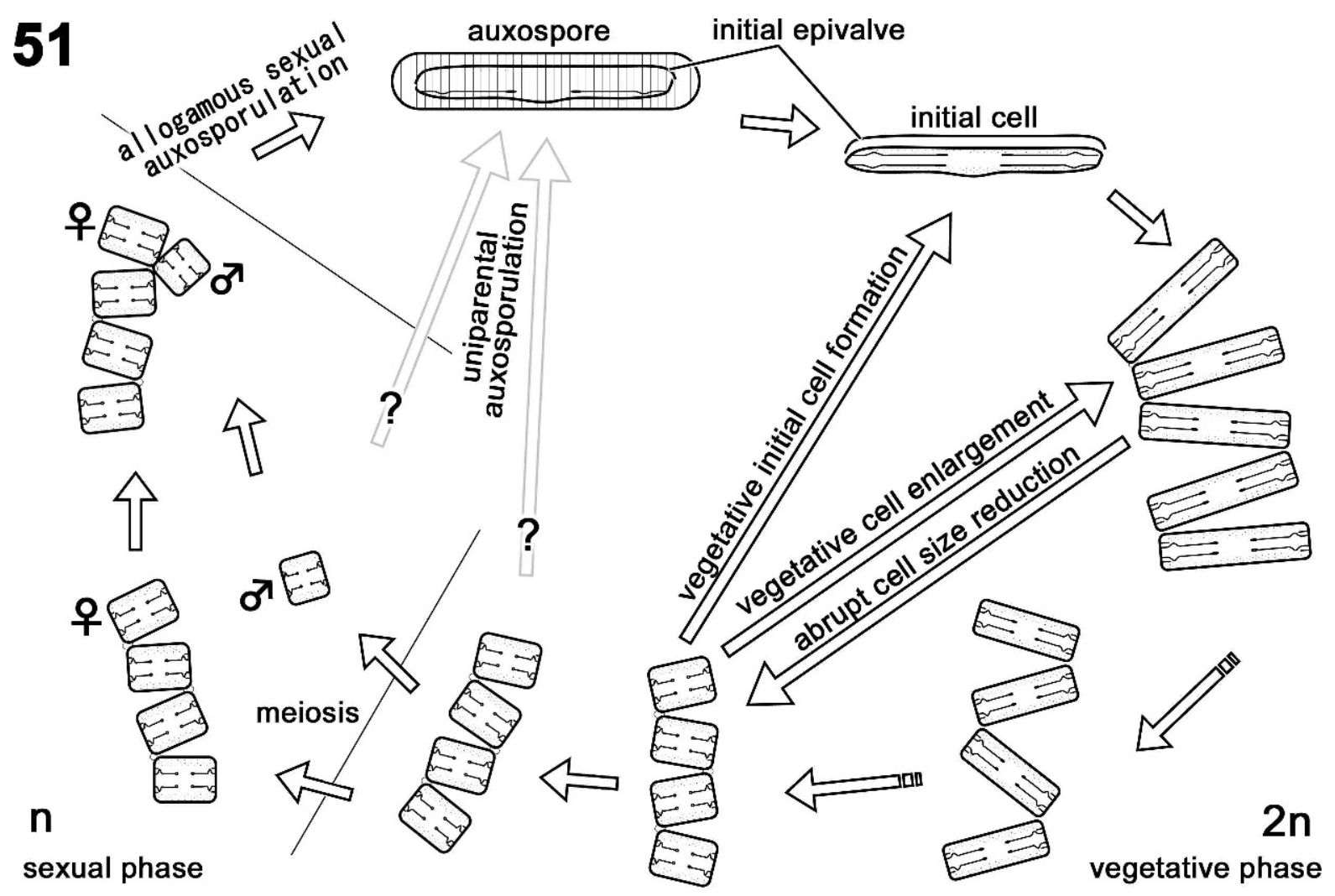

Fig. 51. The life cycle of Grammatophora marina.

1984a), Pinnularia cf. gibba (Poulíčková et al., in press) and Rhoicosphenia curvata (Kützing) Grunow (Mann 1982a). However, open primary bands have been reported in Pseudo-nitzschia multiseries (Kaczmarska et al. 2000) and $N$. fonticola (Trobajo et al. 2006) and it is unclear whether this reflects retention of a primitive character inherited from araphid pennates or homoplasy.

The end of the rib in the primary transverse perizonial band of $G$. marina was sometimes not solid, but perforate (Fig. 21) or hoop-like (Fig. 25), thus resembling an annulus (cf. Fig. 25 with Fig. 18). Given that the primary band also bears fimbriae, it would be reasonable to suggest that it and the scales are homologous.

The irregular siliceous structures on the ventral side of the auxospore of $G$. marina (Fig. 20) are similar in morphology and position to the 'elongate sprawling structure' in G. media (Sato et al. 2004b). These structures extend longitudinally along the suture and may help reinforce the auxospore wall in what would otherwise be a weak point. Longitudinal perizonial bands are formed by various pennate diatoms, including both raphids, e.g. $R$. curvata (Mann 1982a) and A. copulata (Nagumo 2003), and the araphid $R$. arcuatum (von Stosch 1962, 1982). We did not detect any such bands at any stage of auxosporulation in $G$. marina and there is no hint of any from previous studies (Karsten 1926; Lebour 1930; Magne-Simon 1960, 1962). A regular system of pores, resembling the striae of normal valves and initial valves, was sometimes seen beneath the perizonium (Figs 19-21) in auxospores of intermediate length (c. $35 \mu \mathrm{m}$ in Fig. 19), but we interpret these as an abnormally small initial valve (initial cells are usually at least $52.3 \mu \mathrm{m}$ : Table 2).

\section{Initial cell formation}

The initial cells of pennate diatom are generally formed within (and moulded at least in part by) a perizonium consisting of transverse perizonial bands and sometimes also longitudinal perizonial bands (von Stosch 1982). Sexual and 'uniparental' initial cells of $G$. marina conform to this rule, but some other Grammatophora initial cells seem to be formed without production of a perizonium and here there was a higher frequency of deformities, supporting the idea that the perizonium helps to form the correct shape of the initial cell. Several diatoms form auxospores without a transverse perizonium, e.g. Achnanthes brevipes C. Agardh var. intermedia (Kützing) Cleve (Idei 1993), Achnanthes cf. subsessilis Kützing (Sabbe et al. 2004), Achnanthes yaquinensis McIntire \& Reimer (Toyoda et al. 2005), Achnanthes crenulata Grunow (Toyoda et al. 2006), Fragilariforma virescens (Ralfs) Williams \& Round (Williams 2001), Licmophora communis (Heiberg) Grunow (Chepurnov \& Mann 2004), Licmophora gracilis var. anglica (Kützing) Peragallo (Mann 1982b) and Nitzschia recta Hantzsch (Mann 1986), although Achnanthes species have a well-developed system of longitudinal perizonial bands. Williams (2001) proposed that the plethora of peculiar shapes that emerge in the immediate post auxospore valves in $F$. virescens, and presumably in Diatoma moniliformis Kützing (Potapova \& Snoeijs 1997), 
were because of the absence of transverse perizonial bands; this could also be why irregularly shaped and triradiate auxospores (reported by Hendey 1951; Schmid in PickettHeaps et al. 1990; Chepurnov \& Roshchin 1995) are common in Achnanthes spp. (Sabbe et al. 2004).

The initial epitheca of $G$. marina is structurally differentiated from subsequent thecae (reduced or no apical pore fields, no septum and no slits on the valvocopula) and is sloughed off after the formation of a third valve immediately beneath it. Given that we detected no separate longitudinal perizonial bands in G. marina, in contrast to Rhabdonema arcuatum (von Stosch 1962, 1982), it might be argued that we have misinterpreted the longitudinal perizonium as a valve and girdle bands. We reject this because the initial epitheca is formed on the dorsal side of the auxospore, not beneath the suture (contrast the longitudinal perizonia of e.g. Rhabdonema arcuatum, Rhoicosphenia curvata and A. copulata: von Stosch 1962, 1982; Mann 1982a; Nagumo 2003), and because of the presence of a normal stria system. Furthermore, the formation of each valve in diatoms, but not the formation of perizonial bands or girdle bands, is preceded by a mitosis (Geitler 1963; a rare exception during manipulation in culture is discussed by Pollock \& Pickett-Heaps 2006) and Magne-Simon (1962, p. 84) stated that he detected a mitosis before formation of the initial epivalve 'dans de nombreux cas' in G. marina. We regard the acytokinetic mitosis that Magne-Simon (1962, figs 20, 21, and 25) detected after formation of the initial epivalve as that associated with the formation of the initial hypovalve.

The formation of the third valve and loss of the initial epitheca likewise follows mitosis but, unlike the initial epivalve and hypovalve, formation of the third valve is accompanied by an unequal cell division (Magne-Simon 1962, figs 22, 23), the small cell formed under the initial epivalve gaining a nucleus but no or few chloroplasts and little cytoplasm. The small cell occasionally also produced a reduced valve in Magne-Simon's specimens (ibid., fig. 27) but we did not detect any in our material.

\section{Life cycle, cardinal points, and species status of $G$. marina}

In culture, the life cycle of $G$. marina from the United States, Japan and Western Europe exhibits several interesting and unusual features, including two different modes of auxosporulation (sexual and uniparental), vegetative initial cell formation, vegetative cell enlargement and abrupt cell size reduction. Some of the phenomena observed, such as vegetative cell enlargement, abrupt cell size reduction and vegetative formation of initial cells, may perhaps not occur in nature, although Roshchin (1987, 1994) found that monoclonal cultures of G. marina from the Black Sea could also enlarge their cells. The greater size of clonal auxospores, relative to sexual auxospores, makes it highly unlikely that these and the healthy vegetative cells that they produce are haploids as seen in Licmophora species (Chepurnov et al. 2004). Vegetative cell size changes have also been recorded in other diatoms (e.g. von Stosch 1965; Drebes 1966; Mann et al. 2003; Chepurnov et al. 2005). In this study, changing the medium sometimes induced vegetative initial cell formation and vegetative cell enlargement; however, it is unclear which factor(s) triggered these phenomena directly. Long-term culture has often been observed to cause deformities in diatom cell walls (Jaworski et al. 1988; Round 1993; Estes \& Dute 1994), but in our study long periods were not necessary to induce unusual behaviour, sexual and vegetative initial cell formation, and vegetative cell enlargement took place within a month after culture establishment, and uniparental auxosporulation and abrupt cell size reductions took place 7 and 9-12 mo after inoculation, respectively (Table 1).

The absence of sexual reproduction in any of our clones is consistent with previous statements (von Stosch \& Drebes 1964, p. 211; von Stosch in Rozumek 1968, p. 382; Roshchin 1987, 1994) that G. marina is dioecious (heterothallic, i.e. it has separate male and female clones).

The size differences between our material and the $G$. marina population studied by Magne-Simon (1962) seem to be significant. The initial cells reported by Magne-Simon (1962) had a mean length more than double that in our material (Table 2), and the female and male gametangia were also much larger (30-70 vs $19-25 \mu \mathrm{m}$, and 20-50 vs c. $15 \mu \mathrm{m}$, respectively). It is quite likely, therefore, that the two sets of $G$. marina populations represent different races, or even different species. Cryptic or almost cryptic (pseudocryptic) species have been found in Pseudo-nitzschia (Amato et al. 2007), Skeletonema (Medlin et al. 1991; Sarno et al. 2005, 2007; Zingone et al. 2005), and Sellaphora (Behnke et al. 2004; Evans et al. 2007), and also occur in other marine microalgae (e.g. Sáez et al. 2003). Further detailed morphological comparisons (e.g. with morphometric approaches like those conducted by Mann et al. 2004 or Beszteri et al. 2005), together with crossing experiments and molecular genetic studies, will be necessary to determine whether cryptic speciation has occurred in G. marina. Once this has been done, Lyngbye's type material will have to be examined to see whether it is possible to determine which segregate species should bear the name 'marina'.

\section{Ecological implications}

In terms of evolutionary costs and benefits, a long period of cheap asexuality followed by a short period of expensive sexual recombination may be a successful strategy for unicellular organisms, especially if the sexual phase is timed to occur when growth is slow (Lewis 1983, 1984). Vegetative initial cell formation and vegetative cell enlargement may be retained, despite the production of aberrant cell morphology, because they enable sexually competent clones to persist when sexual reproduction is prevented by environmental conditions or availability of compatible mates. Alternatively, vegetative enlargement mechanisms may occur because they provide a less costly means of restoring size than allogamous sexual auxosporulation (although there is still a 'penalty' because cells cannot divide while they are expanding and forming new cell walls), the balance between sexual and nonsexual expansion being determined by the strength of selection for the unique feature of allogamous sexual auxosporulation, viz. meiosis and sexual recombination. Abrupt cell size reduction, if it occurs naturally, will shorten the life cycle (the factor controlling whether cells can be sexualized is cell size, not the age of the 
cell or lineage: von Stosch 1965; Chepurnov et al. 2004). Given that the unperturbed size reduction cycle may last several years in natural populations of diatoms (Mann 1988), a mechanism by which cells could by-pass this time restriction might be beneficial in some circumstances.

A feature of the initial epivalve of $G$. marina is its smaller or less differentiated apical pore fields (e.g. Figs 28, 29), compared to those of the initial hypovalve and vegetative cells (Round et al. 1990; Sato et al. 2004a). It is through the apical pore field that mucilage is secreted for attachment in Grammatophora and many araphid diatoms (Figs 1-3; for a review, see Hasle 1974) and so the initial epivalve is probably unable to attach to a substratum. Even if it could attach, the formation of the third valve close beneath the initial epivalve (Fig. 39) would first disconnect the cytoplasm from the apical region and then lead to detachment when the epivalve is sloughed off (Fig. 31). Furthermore, initial cells produced by uniparental auxosporulation often floated in the culture vessel, whereas most vegetative cells and colonies became attached to the bottom (data not shown). It is possible, therefore, that reduction of the apical pore fields is part of a dispersal mechanism, allowing the initial cells to become temporarily planktonic. The apical pore fields are also reduced in the initial cells of two raphid diatoms, R. curvata and Gomphonema constrictum Ehrenberg (Mann 1984b). Diatoma moniliformis, another zig-zag colonial araphid diatom, is often found in the plankton of the Baltic Sea (Snoeijs 1993), which prompted Potapova \& Snoeijs (1997) to suggest that large cells of the species might switch to pelagic life until they reach a certain minimum size, after which they would return to the benthos. Chepurnov \& Mann (1999, p. 10) noted a tendency of inbred Achnanthes longipes Agardh to become positively buoyant in culture and suggested that this might be an 'escape' mechanism in nature, enhancing the chances of outbreeding. Species of Grammatophora are sometimes reported from the plankton (Karsten 1905; Meunier 1915; Lebour 1930; Ricard 1987; Chiang et al. 1997; Abdul Azis et al. 2001; Eashwar et al. 2001; Koening et al. 2003) and this may perhaps be adaptive, rather than accidental suspension of cells by wave action or macrofaunal activity.

\section{ACKNOWLEDGEMENTS}

We would like to thank Klaus Valentin and William Wardle for providing us the living samples from France and Texas, respectively, used in this study; Friedel Hinz for support with SEM; Victor Chepurnov for helpful comments and information concerning A.M. Roshchin's work; and Richard Crawford for correction of the manuscript and discussion. This study was supported by DAAD (German Academic Exchange Service) for doctoral research fellowship to S.S.

\section{REFERENCES}

Abdul Azis P.K.A., Al-Tisan I. \& Sasikumar N. 2001. Biofouling potential and environmental factors of seawater at a desalination plant intake. Desalination 135: 69-82.
Amato A., Kooistra W.H.C.F., Levialdi Ghiron J.H., ManN D.G., Pröschold T. \& Montresor M. 2007. Reproductive isolation among sympatric cryptic species in marine diatoms. Protist 158: 193-207.

Amato A., Orsini L., D’Alelio D. \& Montresor M. 2005. Life cycle, size reduction patterns, and ultrastructure of the pennate planktonic diatom Pseudo-nitzschia delicatissima (Bacillariophyta). Journal of Phycology 41: 542-556.

AnONymous. 1975. Proposals for a standardization of diatom terminology and diagnoses. Nova Hedwigia, Beiheft 53: 323-354.

Behnke A., Friedl T., Chepurnov V.A. \& Mann D.G. 2004. Reproductive compatibility and rDNA sequence analyses in the Sellaphora pupula species complex (Bacillariophyta). Journal of Phycology 40: 193-208.

Beszteri B., Ács É. \& Medlin L.K. 2005. Conventional and geometric morphometric studies of valve ultrastructural variation in two closely related Cyclotella species (Bacillariophyta). European Journal of Phycology 40: 89-103.

Bold H.C. \& WYNNE J.M. 1985. Introduction to the algae, ed. 2. Prentice-Hall, Englewood Cliffs, NJ. 720 pp.

Chepurnov V.A. \& MANN D.G. 1999. Variation in the sexual behaviour of Achnanthes longipes (Bacillariophyta). II. Inbred monoecious lineages. European Journal of Phycology 34: 1-11.

Chepurnov V.A. \& Mann D.G. 2004. Auxosporulation of Licmophora communis (Bacillariophyta) and a review of mating systems and sexual reproduction in araphid pennate diatoms. Phycological Research 52: 1-12.

Chepurnov V.A., Mann D.G., Sabbe K., Vannerum K., Casteleyn G., Verleyen E., Peperzak L. \& Vyverman W. 2005. Sexual reproduction, mating system, chloroplast dynamics and abrupt cell size reduction in Pseudo-nitzschia pungens from the North Sea (Bacillariophyta). European Journal of Phycology 40: 379-395.

Chepurnov V.A., Mann D.G., Sabbe K. \& Vyverman W. 2004. Experimental studies on sexual reproduction in diatoms. International Review of Cytology 237: 91-154.

Chepurnov V.A. \& Roshchin A.M. 1995. Inbreeding influence on sexual reproduction of Achnanthes longipes Ag. (Bacillariophyta). Diatom Research 10: 21-29.

Chinng K.P., Shiah F.K. \& Gong G.C. 1997. Distribution of summer diatom assemblages in and around a local upwelling in the East China Sea northeast of Taiwan. Botanical Bulletin of Academia Sinica 38: 121-129.

Cohn S.A., Spurck T.P., Pickett-Heaps J.D. \& Edgar L.A. 1989. Perizonium and initial valve formation in the diatom Navicula cuspidata (Bacillariophyceae). Journal of Phycology 25: 15-26.

CRAWFORD R.M. 1974. The auxospore wall of the marine diatom Melosira nummuloides (Dillw.) C. Ag. and related species. British Phycological Journal 9: 9-20.

DrEBES G. 1966. On the life history of the marine plankton diatom Stephanopyxis palmeriana. Helgoländer wissenschaftlicher Meeresuntersuchungen 13: 101-114.

Eashwar M., Kuberaraj K., Nallathambi T. \& Govindarajan G. 2001. A note on the plankton from Barren Island region, Andamas. Scientific Correspondence 81: 651-654.

Edlund M.B. \& Stoermer E.F. 1997. Ecological, evolutionary, and systematic significance of diatom life histories. Journal of Phycology 33: 897-918.

Eppley R.W., Holmes R.W. \& Strickland J.D.H. 1967. Sinking rates of the marine phytoplankton measured with a fluorochrometer. Journal of Experimental Marine Biology and Ecology 1: 191-208.

Estes L. \& Dute R.R. 1994. Valve abnormalities in diatom clones maintained in long-term culture. Diatom Research 9: 249-258.

Evans K.M., Wortley A.H. \& Mann D.G. 2007. An assessment of potential diatom "barcode" genes ( $\operatorname{cox} 1, r b c \mathrm{~L}, 18 \mathrm{~S}$ and ITS rDNA) and their effectiveness in determining relationships in Sellaphora (Bacillariophyta). Protist 158: 349-364.

GeITLER L. 1932. Der Formwechsel der pennaten Diatomeen. Archiv für Protistenkunde 78: 1-226.

Geitler L. 1963. Alle Schalenbildungen der Diatomeen treten als Folge von Zell- oder Kernteilungen auf. Berichte der Deutschen Botanischen Gesellschaft 75: 393-396.

Hasle G.R. 1974. The "mucilage pore" of pennate diatoms. Nova Hedwigia, Beiheft 45: 167-194. 
HeNDEY N.I. 1951. Littoral diatoms of Chichester Harbour with special reference to fouling. Journal of the Royal Microscopical Society 71: 1-86.

IDEI M. 1993. [Achnanthes brevipes C. Agardh var. intermedia (Kützing) Cleve.]. In: An illustrated atlas of the life history of algae, vol. 3. Unicellular and flagellated algae (Ed. by T. Hori), pp. 260-261. Uchida Rokakuho, Tokyo. (in Japanese)

JAWORSKi G.H.M., Wiseman S.W. \& REYNOLDS C.S. 1988 Variability in sinking rate of the freshwater diatom Asterionella formosa: the influence of colony morphology. British Phycological Journal 23: 167-176.

Kaczmarska I., Bates S.S., Ehrman J.M. \& Léger C. 2000. Fine structure of the gamete, auxospore and initial cell in the pennate diatom Pseudo-nitzschia multiseries (Bacillariophyta). Nova Hedwigia 71: 337-357.

KacZMARSKA I., Ehrman J.M. \& BATES S.S. 2001. A review of auxospore structure, ontogeny and diatom phylogeny. In: Proceedings of the 16th International Diatom Symposium (Ed. by A. Economou-Amilli), pp. 153-168. University of Athens, Greece.

Karsten G. 1905. Das Phytoplankton des Antarktischen Meeres nach dem Material der Deutschen Tiefsee-Expedition 1898-1899. Wissenschaftliche Ergebnisse der Deutschen Tiefsee-Expedition auf dem Dampfer Valdivia 1898-1899 2: 1-136.

Karsten G. 1926. Die Tabellarien und ihre Auxosporenbildung. Leopoldina 1: 65-68.

Kobayashi A., Osada K., Nagumo T. \& Tanaka J. 2001. An auxospore of Arachnoidiscus ornatus Ehrenberg. In: Proceedings of the 16th International Diatom Symposium (Ed. by A Economou-Amilli), pp. 197-204. University of Athens, Greece.

Koening M.L., Leça E.E., Neumann-Leitào S. \& de Macèdo S.J. 2003. Impacts of the construction of the port of Suape on phytoplankton in the Ipojuca River estuary (PernambucoBrazil). Brazilian Archives of Biology and Technology 46: 73-81.

LEBOUR M. 1930. The plankton diatoms of northern seas. Ray Society, London. $244 \mathrm{pp}$.

LEWIS W.M. Jr. 1983. Interruption of synthesis as a cost of sex in small organisms. American Naturalist 121: 825-833.

LEWIS W.M. Jr. 1984. The diatom sex clock and its evolutionary importance. American Naturalist 123: 73-80.

Magne-Simon M.-F. 1960. Note sur le processus de l'auxosporulation chez une Diatomée marine, Grammatophora marina (Lyngbye) Kützing. Comptes rendus de l'Académie des Sciences (Paris) 251: 3040-3042.

Magne-Simon M.-F. 1962. L'auxosporulation chez une Tabellariacée marine, Grammatophora marina (Lyngbye) Kützing. Cahiers de Biologie Marine 3: 79-89.

MANN D.G. 1982a. Structure, life history and systematics of Rhoicosphenia (Bacillariophyta). II. Auxospore formation and perizonium structure of Rh. curvata. Journal of Phycology 18: $264-274$.

MANN D.G. 1982b. Auxospore formation in Licmophora (Bacillariophyta). Plant Systematics and Evolution 139: 289-294.

MANN D.G. 1984a. Auxospore formation and development in Neidium (Bacillariophyta). British Phycological Journal 19: 319-331.

MANN D.G. 1984b. Structure, life history and systematics of Rhoicosphenia (Bacillariophyta) V. Initial cell and size reduction in Rh. curvata. and the description of the Rhoicospheniaceae, fam. nov. Journal of Phycology 20: 544-555.

MANN D.G. 1986. Methods of sexual reproduction in Nitzschia: systematic and evolutionary implications (Notes for a monograph of the Bacillariaceae 3). Diatom Research 1: 193-203.

ManN D.G. 1988. Why didn't Lund see sex in Asterionella? A discussion of the diatom life cycle in nature. In: Algae and the aquatic environment (Ed. by F.E. Round), pp. 383-412. Biopress, Bristol.

MANN D.G. 1989. On auxospore formation in Caloneis and the nature of Amphiraphia (Bacillariophyta). Plant Systematics and Evolution 163: 43-52.

Mann D.G., Chepurnov V.A. \& Idei M. 2003. Mating system, sexual reproduction and auxosporulation in the anomalous raphid diatom Eunotia (Bacillariophyta). Journal of Phycology 39: $1067-1084$.
Mann D.G., McDonald S.M., Bayer M.M., Droop S.J.M., Chepurnov V.A., Loke R.E., Ciobanu A. \& du Buf J.M.H. 2004. Morphometric analysis, ultrastructure and mating data provide evidence for five new species of Sellaphora (Bacillariophyceae). Phycologia 43: 459-482.

Medin L.K., Elwood H.J., Stickel S. \& Sogin M.L. 1991. Morphological and genetic variation within the diatom Skeletonema costatum (Bacillariophyta): evidence for a new species, Skeletonema pseudocostatum. Journal of Phycology 27: 514 524.

MEDLIN L.K. \& KaCZMARSKA I. 2004. Evolution of the diatoms: V. Morphological and cytological support for the major clades and a taxonomic revision. Phycologia 43: 245-270.

Meunier A. 1915. Microplancton de la Mer Flamande. Part 2. Les Diatomacées. Mémoires du Musée Royale d' Histoire Naturelle de Belgique 7: 1-118.

Nagumo T. 2003. Taxonomic studies of the subgenus Amphora Cleve of the genus Amphora (Bacillariophyceae) in Japan. Bibliotheca Diatomologica 49: 1-265.

NAGUMO T. \& KoBAyASI H. 1990. The bleaching method for gently loosening and cleaning a single diatom frustule. Diatom 5: 45-50.

Ohgai M., Tsuchida H., Syazuki T., Nakashima K., Ueda K. \& SAKUMA M. 1988. Effects of the environmental factors on the propagation of epiphytic diatom Grammatophora marina (Lyngb.) Kütz. Nippon Suisan Gakkaishi 54: 795-799. (in Japanese with English abstract)

Pickett-Heaps J.D., Schmid A.-M.M. \& Edgar L.A. 1990. The cell biology of diatom valve formation. Progress in Phycological Research 7: 1-168.

Pollock F.M. \& Pickett-Heaps J.D. 2006. Valve formation without mitosis in the diatom Ditylum recovering from plasmolysis. Nova Hedwigia, Beiheft 130: 119-126.

Potapova M. \& Snoeiss P. 1997. The natural life cycle in wild populations of Diatoma moniliformis (Bacillariophyceae) and its disruption in an aberrant environment. Journal of Phycology 33: 924-937.

PoulíčKovÁ A. \& MANN D.G. 2006. Sexual reproduction in Navicula cryptocephala (Bacillariophyceae). Journal of Phycology 42: 872-886.

Poulíčková A., Mayama S., Chepurnov V.A. \& Mann D.G. Heterothallic auxosporulation, incunabula and perizonium in Pinnularia (Bacillariophyceae). European Journal of Phycology. In press.

ReimanN B. 1960. Bildung, Bau und Zusammenhang der Bacillariophyceenschalen. (Elektronenmikroskopische Untersuchungen) Nova Hedwigia 2: 349-373.

RICARD M. 1987. Atlas du phytoplancton marin. Volume II. Diatomophycées. Éditions du CNRS, Paris. 297 pp.

Roshchin A.M. 1987. Odnodomnoe vosproizvedenie diatomovoj vodorosli Grammatophora marina. Biologicheskie Nauki. (Moscow) 6: 65-69.

Roshchin A.M. 1994. Zhiznennye tsikly diatomovykh vodoroslej. Naukova Dumka, Kiev. 170 pp.

Round F.E. 1993. A Synedra (Bacillariophyta) clone after several years in culture. Nova Hedwigia, Beiheft 106: 353-359.

Round F.E., CRAWford R.M. \& MANn D.G. 1990. The diatoms. Biology and morphology of the genera. Cambridge University Press, Cambridge. 747 pp.

RozumeK K.E. 1968. Der Einfluss der Umweltfaktoren Licht und Temperatur auf die Ausbildung der Sexualstadien bei der pennaten Diatomee Rhabdonema adriaticum Kütz. Beiträge zur Biologie der Pflanzen 44: 365-388.

Sabbe K., Chepurnov V.A., Vyverman W. \& Mann D.G. 2004. Apomixis in Achnanthes (Bacillariophyceae); development of a model system for diatom reproductive biology. European Journal of Phycology 39: 327-341.

SÁez A.G., Probert I., Geisen M., Quinn P., Young J.R. \& MedLin L.K. 2003. Pseudocryptic speciation in coccolithophores. Proceedings of the National Academy of Sciences of the United States of America 100: 7163-7168.

Sarno D., Kooistra W.C.H.F., Balzano S., Hargraves P.E. \& ZINGONE A. 2007. Diversity in the genus Skeletonema (Bacillariophyceae): III. Phylogenetic position and morphological vari- 
ability of Skeletonema costatum and Skeletonema grevillei, with the description of Skeletonema ardens sp. nov. Journal of Phycology 43: 156-170.

Sarno D., Kooistra W.C.H.F., Medlin L.K., Percopo I. \& ZINGONE A. 2005. Diversity in the genus Skeletonema (Bacillariophyceae). II. An assessment of the taxonomy S. costatum-like species, with the description of four new species. Journal of Phycology 41: 151-176.

Sato S., Nagumo T. \& Tanaka J. 2004a. Morphology and taxonomy of marine attached diatoms in genus Grammatophora Ehrenberg (Bacillariophyceae) in Japan. Japanese Journal of Phycology 52, supplement: 183-187.

Sato S., Nagumo T. \& Tanaka J. 2004b. Auxospore formation and the morphology of the initial cell of the marine araphid diatom Gephyria media (Bacillariophyceae). Journal of Phycology 40: 684-691.

SCHMid A.-M.M. \& CRAwFord R.M. 2001. Ellerbeckia arenaria (Bacillariophyceae): formation of auxospores and initial cells. European Journal of Phycology 36: 307-320.

SNOEIJS P. [Ed] 1993. Intercalibration and distribution of diatom species in the Baltic Sea, vol. 1. Opulus Press, Uppsala. 129 pp.

South G.R. \& Whitтick A. 1987. Introduction to phycology. Blackwell Science, Oxford. 341 pp.

Sтоsch H.A. von. 1962. Über das Perizonium der Diatomeen. Vorträge aus dem Gesamtgebiet der Botanik 1: 43-52.

Sтоsch H.A. von. 1965. Manipulierung der Zellgrösse von Diatomeen in Experiment. Phycologia 5: 21-44.

Stosch H.A. von. 1982. On auxospore envelopes in diatoms. Bacillaria 5: 127-156.

Stosch H.A. von. \& Drebes G. 1964. Entwicklungsgeschichtliche Untersuchungen an zentrischen Diatomeen IV. Die Planktondiatomee Stephanopyxis turris - ihre Behandlung und Entwicklungsgeschichte. Helgoländer wissenschaftliche Meeresuntersuchungen 11: 209-257.
Tiffany M.A. 2005. Diatom auxospore scales and early stages in diatom frustule morphogenesis: their potential for use in nanotechnology. Journal of Nanoscience and Nanotechnology 5: 131-139.

Toyoda K., Idei M., Nagumo T. \& Tanaka J. 2005. Finestructure of the vegetative frustule, perizonium and initial valve of Achnanthes yaquinensis (Bacillariophyta). European Journal of Phycology 40: 269-279.

Toyoda K., Williams D.M., Tanaka J. \& Nagumo T. 2006. Morphological investigations of the frustule, perizonium and initial valves of the freshwater diatom Achnanthes crenulata (Bacillariophyceae). Phycological Research 54: 173-182.

Trobajo R., Mann D.G., Chepurnov V.A., Clavero E. \& Cox E.J. 2006. Auxosporulation and size reduction pattern in Nitzschia fonticola (Bacillariophyta). Journal of Phycology 42: 1353-1372.

Williams D.M. 2001. Comments on the structure of "postauxospore' valves of Fragilariforma virescens. In: Lange-Bertalot Festschrift, studies on diatoms (Ed. by R. Jahn, J.P. Kociolek, A. Witkowski \& P. Compère), pp. 103-117. A.R.G. Gantner, Ruggell, Liechtenstein.

Witkowski A., Lange-Bertalot H. \& Metzeltin D. 2000. Diatom flora of marine coasts I. Iconographia Diatomologica 7 : $1-925$.

Zingone A., Percopo I., Sims P.A. \& Sarno D. 2005. Diversity in the genus Skeletonema (Bacillariophyceae). I. A reexamination of the type material of $S$. costatum. with the description of $S$. grevillei sp. nov. Journal of Phycology 41: 140-150.

Received 15 May 2007; accepted 16 August 2007 Associate editor: Marina Potapova 